\title{
The value of online banking to small and medium- sized enterprises: evidence from firms operating in the UAE free trade zones
}

\author{
Parvaneh Shahnoori \\ Department of Economics, Payame Noor University, Bandar Abbas, Iran \\ E-mail:pshahnoori@gmail.com \\ Glenn P. Jenkins \\ Department of Economics, Queen's University, Kingston, Canada and \\ Eastern Mediterranean University, North Cyprus \\ E-mail: jenkins@econ.queensu.ca
}

\section{Development Discussion Paper: 2019-14}

\begin{abstract}
This study estimates the willingness to pay of small and medium-sized enterprises (SMEs) for a business online banking service. The estimation utilizes a contingent valuation method employing data from 400 SMEs in the United Arab Emirates free zones. An interval regression model is used to identify company characteristics affecting WTP. The results indicate an average WTP for online banking of $\$ 518.50$ per month. Firms engaging in international trade value these services at least $10 \%$ more than those with only domestic operations. Other variables that significantly affect WTP include number of employees and the transportation cost of using traditional branch banking.
\end{abstract}

Keywords: Contingent Valuation Method, Interval Regression Model, Willingness to Pay, Business Online Banking

JEL Codes: C13; F10; G21

Revised Version Published as: Parvaneh Shahnoori \& Glenn P. Jenkins (2019) The value of online banking to small and medium-sized enterprises: evidence from firms operating in the UAE free trade zones, Applied Economics 2019, Vol 51: No.37, pp 4046-4055 


\section{Introduction}

Business online banking offers secure and easy access to banking services, enabling the online payment of bills, receipt of funds, and funds transfer at a lower cost to the customer than that of traditional banking. Most SMEs in developing countries face a range of challenges. On the one hand, they are often required to conduct their business without a proper financial infrastructure to operate efficiently, and on the other hand, they have to satisfy their customers' preferences. Online banking services can help them to save time (Calisir and Gumussoy 2008). This is particularly the case for SMEs engaging in international trade, where wire transfers and opening letters of credit are needed. In the absence of a high-quality online banking system, these are time consuming and, hence, expensive transactions for the firm. We would expect to find that such firms are willing to pay a premium for access to online banking services.

The use of online banking means that owners/ managers or specific employees of SMEs do not have to spend time and pay transportation costs to go to a bank branch and then wait in a queue to perform their banking transactions. In addition to the savings in time and cost, online banking services give the owner/manager the opportunity to check the firm's transactions and available cash, anytime and anywhere. The online service also increases the satisfaction levels of the SMEs' customers and suppliers, since they can pay and be paid for their business transactions online and receive notification for every transaction. One of most important problems that banks' clients face is internal bank fraud. Cummins, Lewis, and Wei (2006) reported that in the USA, $23.2 \%$ of bank accounts faced some type of internal fraud. Apart from the above-mentioned advantages, online banking provides accessibility that gives SME 
owners/managers the ability to check their bank accounts frequently and, hence, to detect more quickly any mistake or fraudulent behavior on the part of bank personnel.

Electronic banking reduces the operational costs of banks (Jordan and Katz 1999; Polatoglu and Ekin 2001) and individual transaction costs (Jayawardhena and Foley 2000). According to Jayawardhena and Foley (2000), the cost of a simple transaction performed using the traditional bank branch is 11 times more than one performed through online banking. Another study (The Dominion 2001) found that the cost to a bank of an online transaction is $\$ 0.05$ per transaction, while the same transaction through a bank branch costs $\$ 1$.

The objective of this study is to identify the determinants and measure the WTP by SMEs for secure online banking services that are available 24/7. To obtain a data set with a high concentration of SMEs engaged in international trade, a survey was conducted of SMEs operating in the free trade zones of the United Arab Emirates (UAE). At the time the survey was conducted, the banking system in the UAE did not provide a modern secure online banking service. It is a common belief that strong SME performance speeds up economic growth and decreases poverty (Beck, Demirguc-Kunt, and Levine 2005).

Engagement in international trade becomes an important feature of SMEs, as these firms often have lower cost and are more productive (Bernard et al. 2007). Providing low-cost banking services would serve to improve further the competitive position of these firms. A common problem in transition countries is that the laws and regulations governing online banking have lagged behind the advances in technology that are now available to provide this service. In many such countries, the government needs to 
modernize the banking regulations to allow banking customers and banks to enjoy the economic benefits of this innovation. This study attempts to quantify the benefits to be gained by implementing online banking services for firms in the SME sector.

To our knowledge our study is the first to estimate the monetary value that consumers are willing to pay for online banking services. There is an extensive literature on the identification of the attributes of the service that individuals feel are important, but no estimate has been made of the monetary value of the service for either personal banking or the banking services undertaken for the purpose of the business of a firm.

\section{Background}

Different facets of online banking have been studied by researchers in this field. Aladwani (2001) investigated the characteristics of online banking from the point of view of both banks and consumers. He concluded that for consumers the service is faster, easier to use, and more reliable than traditional banking. From the point of view of banks, he showed that the service improves their image and competitive position, establishes a valuable market, reduces operating and administrative cost, and decreases the number of employees required.

Some of the studies on online banking have considered the reasons for the adoption of online banking, while others have identified the main reasons that online banking has been rejected. For example, Martins, Oliveira, and Popovič (2014) found that the important determinants for online banking adoption are performance and ease of effort, social influence, and perceived risk. Yiu, Grant, and Edgar (2007) found a positive relationship between personal innovativeness and perceived risk with 
online banking adoption. Yousafzai, Pallister, and Foxall (2003) found the most important reasons for online banking adoption to be trust and security.

Al-Somali, Gholami, and Clegg (2009) found the determinants of online banking adoption to be consumers' perception of the quality of the internet connection, consumers' awareness of e-banking services, perceived usefulness, and perceived ease of use. In addition to findings on the adoption of online banking, Eriksson and Nilsson (2007) identified perceived usefulness and satisfaction to be two important reasons for customers to continue their use of e-banking.

Sathye (1999) identified some obstacles to online banking, namely concerns about security and the lack of awareness about online banking. Kuisma, Laukkanen, and Hiltunen (2007) concluded that the rejection of online banking is often caused by psychological concerns, such as the absence of an official receipt, and functional barriers, such as a lack of computer skills and the absence of information on the nature of online banking.

Studies have also been undertaken to identify the reasons why some banks are successful in implementing online banking. Shah and Siddiqui (2006) found the main factor to be the re- engineering of the managerial structure of the bank in order to accelerate the decision-making procedure and to integrate online banking with the other service delivery channels. This motivation should be particularly strong in the case of Banks providing online banking services to SMEs engaged in international trade. Wire transfers and opening of letters of credit are important components of the financial transactions of such enterprises and are expensive in terms of time and effort for both the customer and the bank when carried out as in bank transactions. 
As the literature review for this study indicates, there does not appear to be any published studies to date that measure the monetary value of the service to the customer.

\section{Methodology}

We used the contingent valuation method (CVM) to elicit SMEs' WTP for an improved online banking service by asking participants to demonstrate their WTP according to the payment card selected. We then applied a maximum likelihood estimation, using an interval regression model to estimate SMEs' WTP for the service. To the best of our knowledge, this is the first study to seek to establish the WTP for business online banking by employing such CVM techniques.

\section{Contingent valuation method}

CVM was introduced theoretically in 1947 and first applied in practice in 1963 (Venkatachalam 2004). It is a tool that is commonly used to estimate the economic value of environmental and public goods, to compare actual and hypothetical WTP, and to measure welfare (Hanemann 1984; Seip and Strand 1992; Blaine, Lichtkoppler, and Stanbro 2003; Bosetti and Pearce 2003; Zhongmin et al. 2003; Nomura and Akai 2004; Mahieua, Rierab, and Giergicznyc 2012; Ozbafli and Jenkins 2015). This research technique has been used to examine non-environmental issues, such as improved services (Saz-Salazar and Garcia- Menendez 2001; Kim 2005; Ajayi 2006; Cawley 2008; Lindhjem and Navrud 2011). CVM is also used to estimate the willingness to accept (WTA) environmental goods, and in marketing studies aimed at 
estimating the value to consumers of new products (Amigues et al. 2002). However, the reliability and validity of this method has been criticized by some scholars (Hausman 1993; Diamond and Hausman 1994; Hausman 2012).

In this application to the measurement of the WTP for online banking services, the usual problems of consistency and accuracy of CVM are not as serious as those found in many other studies. This study uses CVM to elicit the SMEs' valuation of online banking, which cannot be considered a public good. In many CV studies, the method is used to estimate the consumers' non-use value ${ }^{1}$ (Diamond 1996) of a public good that is not purchased by the consumers directly (Diamond and Hausman 1994). As online banking is a private, not a public, good, the results of the survey can be compared with the actual demand for online banking services in other available markets (Diamond 1996). Hence, we can have more confidence in CVM to estimate the WTP for this service accurately.

To determine customers' WTP for a new good or improved service, economists create a contingent market and ask participants about their WTP for that product. Such research entails two types of questions: open-ended and dichotomous. One type of open-ended question is sequential bidding, in which participants respond verbally or using payment cards: respondents are asked to indicate the highest value they would be willing to pay by selecting one of a range of payment cards (Cameron and Huppert 1989).

The first step in conducting our research was to identify the market or customers. Our contingent market in the UAE free zones comprised 400 SMEs, most of which were engaged in international trade. The owners/managers of these SMEs were invited to participate in our hypothetical market for business online banking services, using 
payment cards. Cameron and Huppert (1989) compared two approaches to estimating WTP, namely ordinary least square (OLS) and maximum likelihood (ML). According to their findings, the OLS approach yields inaccurate results because the interval midpoints are used as the stated WTP, producing inconsistent parameter estimates (Voltaire 2015). We therefore used the ML method.

In such studies where the dependent variable does not have a specific observed valuerather, its value lies within a continuous interval - interval regression models may be used to estimate the parameter in the CVM. For example, Loureiro, and, and Hine (2002) utilizeda multiple bounded probit model 'to quantify factors affecting consumer preferences among organic, GMO-free, and Colorado-grown potatoes.' Voltaire (2015) used a switching interval regression to analyze WTP for new products. Other interval methods are regression quantile techniques (Lee and Tanaka 1999) and a censored regression model (Cameron 1991).

\section{Maximum likelihood interval estimation method}

The payment card system is widely used as a means of establishing WTP for a nonmarket product, while the ML approach has been found to be an appropriate means of interval estimation (Voltaire 2015). In this study, we used Cameron and Huppert's model (1989) to estimate SMEs' WTP for an online banking service, from data collected using payment cards. Rather than use their log form, we used a linear form for WTP.

We defined the lower and upper boundaries of the payment card chosen by the respondent as tli and tui, respectively, and assumed that respondents' actual WTP lies between these two values (Loureiro, And, and Hine 2002). Therefore, WTP will lie within tli and tui, according to the general assumption: 


$$
E\left(\left(w t p \mid x_{i}\right)\right)=g\left(x_{i}, \beta\right)
$$

and

Therefore:

$$
g\left(x_{i}, \beta\right)=x_{i}^{\prime} \beta
$$

$$
W T P=x_{i}^{\prime} \beta+u_{i}
$$

Where ui is distributed normally with mean 0 and standard deviation $\sigma$, and $x^{\prime} i$ is a vector of independent variables that influence the SME's WTP for different service attributes, the characteristics of the owner, or the SME's business activities. After standardizing the pair of thresholds, we obtained:

$$
\operatorname{pr}\left(W T P_{i} \subseteq\left(t_{l i}, t_{u i}\right)\right)=\operatorname{pr}\left(t_{l i}-x_{i}^{\prime} \beta / \sigma<z_{i}<t_{u i}-x_{i}^{\prime} \beta / \sigma\right)
$$

Where zi is the standard normal random variable. After some manipulation, equation (4) can be written as:

$$
\operatorname{pr}\left(W T P_{i} \subseteq\left(t_{l i}, t_{u i}\right)\right)=\Phi\left(z_{u i}\right)-\Phi\left(z_{l i}\right)
$$

where $\Phi$ is the cumulative standard normal den- sity function. The joint probability of $\mathrm{n}$ independent observations is equal to the log- likelihood function, as follows:

$$
\log L=\sum_{i=1}^{n} \log \left[\Phi\left(z_{u i}\right)-\Phi\left(z_{l i}\right)\right]
$$

By estimating equation (6), one can establish the value that consumers place on a good or service (Loureiro, and, and Hine 2002).

\section{Survey and data}

Using the stratified sample method, we selected 400 SMEs from six free zones in the UAE 67 from Dubai, 120 from Jebel Ali, 14 from Hamriyah, 80 from Sharjah, 33 from Ajman, and 
86 from Ras Al Khaimah. The number of companies selected from each free zone is proportional to the total number of companies in each zone, as per the UAE Free Zones Directory (Global Resources 2012). We conducted interviews with SME owners/managers in the period October to December 2014. We tested the questionnaire in a pilot study involving the owners/managers of 40 companies.

The interview process began with an outline of the key features of a state-of-the-art business online banking system for SMEs. ${ }^{2}$ Respondents were then asked whether they would like to participate in the researchers' contingent market - that is, if it was available, would they choose to use a business online banking system? Of the 400 respondents surveyed, 14 stated that they would not choose to use a business online banking service. This group was then asked why they would not choose to use such a service. Because WTP is conditional on a preference for choosing the proposed good or service - in this case, business online banking services - the sample size was reduced to 386. This group was asked to identify threshold values for online banking services, which the researchers used to develop service payment cards.

If respondents were unable to assign a specific value to online banking, they were asked to put a tick next to the minimum amount they would be willing to pay for such services, and a cross next to the maximum amount. In this way, the upper and lower bounds would be found and the unobserved willingness would lie within this interval. This approach facilitates a more accurate assessment of WTP, as most respondents are better able to indicate the range within which their WTP lies, rather than an exact figure (Cameron and Huppert 1989).

First, business online banking was introduced. The attributes, benefits, and different 
options of this service were defined in detail and the respondents were then asked to state their WTP for the service. Since the data were collected through face-to- face interviews, we had the chance to answer respondents' questions if there was any ambiguity, and to clarify the options and advantages of the service over the alternative banking services. All 386 participating SME owners/managers responded to this part of the interview. Traditional banking imposes two types of costs on SMEs: transport costs (to the bank branch) and opportunity costs (employee/owner time). As the actual time spent carrying out the banking transactions - and, hence, the labor cost -is unknown, the proxy used to measure the impact of traditional banking costs on the WTP is the monthly frequency of bank visits, in terms of the direct transport costs.

\section{Sample companies' descriptive statistics}

Table 1-8 provide an overview of sample companies by sector of activity, gender, and mean age of the owner/manager, number of employees, engagement in international trade, and level of education of the owner/manager. From Table 1 we can see that over half of the firms surveyed (56.22\%) were engaged in trade. A further $37.57 \%$ were engaged in either services or services and trade. Table 2 shows that over $80 \%$ of the sample of SME firms were engaged in international trade as importers or exporters, or both.

Table 1. Sample SMEs' sector of activity.

Sector $\quad$ Frequency Percentage

Production

12

97
3.11

25.13 
Production and Trade

Table 2. Sample SMEs' engagement in international trade.

Yes

320

$82.90 \%$
No

66

$17.10 \%$

With regard to the gender of the owner of the firms, the majority were male (91\%), as reported in Table 3. As shown in Table 4, the entrepreneur's operating in the free zones are relatively young, with ages ranging from 22 to 68 years and a mean of 42.4 years. An interesting feature of these SMEs is their size. They are small, with the number of employees ranging from 2 to 72 and an overall average of 11 employees per firm. Nevertheless, these firms are rather dynamic, as attested by the fact that more than $80 \%$ are engaged in international trading activities.

Table 6 shows the education level of the owners of these firms. It is surprisingly high. 
About $70 \%$ of the total (268 owners) had completed a university degree, and 67 had completed a master's degree or PhD. Hence, these owners' time is likely to have a relatively high opportunity cost. They are also likely to be experienced in using web-based interfaces.

In Table 7 we report the attitudes of those surveyed on the quality of the existing banking services. Clearly, from the perspective of these firms, the

Table 3. Sample SME owners' gender.

Gender

Male

Female

Total
Frequency

350

36

386
Percentage

90.67

9.33

100

Table 4. Sample SME owners' mean age.

\begin{tabular}{lccccc} 
Variable & Number of Observations & Mean & Std. Dev. & Min & Max \\
\hline Age & 386 & 42 & 11.22 & 22 & 68 \\
\hline
\end{tabular}

Table 5. Sample SMEs' number of employees.

Variable

Number of employees
Number of Observations Mean

386

11.1606

Std. Dev. Min Max

$\begin{array}{lll}7.13 & 2 & 72\end{array}$


Table 6. Sample SME owners' education level.

\begin{tabular}{lccc} 
Education level & Frequency & Percentage & Cumulative (\%) \\
\hline Secondary school & 21 & 5.44 & 5.44 \\
High school & 95 & 24.61 & 30.05 \\
University & 203 & 52.59 & 82.64 \\
Master & 62 & 16.06 & 98.70 \\
PhD & 5 & 1.30 & 100 \\
Total & 386 & 100 & \\
\hline
\end{tabular}

Table 7. Attitudes to current banking s ervices.

Question: On a scale of 1 to 5 (where 1 is low), how would you rate the services currently available through your bank branch?

\begin{tabular}{lccc}
\hline Ranking Scale & Frequency & Percentage & Cumulative (\%) \\
\hline 1 & 17 & 4.40 & 4.40 \\
2 & 90 & 23.32 & 27.72 \\
3 & 154 & 39.90 & 67.62 \\
4 & 80 & 20.73 & 88.34 \\
5 & 45 & 11.66 & 100 \\
Total & 386 & 100 & \\
\hline
\end{tabular}


Quality of the existing banking services provided in the UAE has considerable room for improvement. Of the 386 respondents surveyed, $67.62 \%$ believe that the current bank services are not good (4.40\% very bad, $23.32 \%$ bad, $39.90 \%$ neither bad nor good), with the remainder reporting that the current bank services are good $(20.73 \%)$ or very good (11.66\%). Some $59 \%$ of respondents stated that banking transactions take an average of more than 30 minutes each at the bank, while $66.5 \%$ believe that traditional banking is more costly than online banking.

As previously reported, 386 companies stated that they would choose online banking services (i.e. would participate in our hypothetical market) and 14 stated that they would not. The former group is therefore assigned a positive WTP, and the latter zero WTP. Table 8. Percentage breakdown by WTP and reason for not choosing online banking.

\section{Econometric results}

We used an interval regression model to identify the effect of respondent characteristics on WTP for online banking services.

Table 8 shows the percentage breakdown by WTP and the reasons that zero-WTP companies would not choose online banking. Would not choose online banking.

\begin{tabular}{lc}
\hline Measure & Percentage \\
\hline Positive WTP (would participate in market) & 96.50 \\
Zero WTP (would not participate in market) & 3.50 \\
Total observations = 400 & 100 \\
Reasons for not choosing & 57.20 \\
The current service is adequate & 21.40 \\
The service should be free & 14.30 \\
Do not have computer knowledge & 7.10 \\
It is complicated; we do not need it & 7 \\
\hline
\end{tabular}


Using STATA software, we regressed the lower and upper boundaries of WTP on owner age, gender, and level of education, as well as company features: number of employees (indicative of company size), transportation cost to get to the bank, sector (production, services, trade, production and trade, or services and trade), and whether the company is engaged in international trade. Cameron and Huppert (1989) stated that they preferred to use a log form for the dependent variable, as the results of most previous studies showed the WTP to be positively skewed. Following their model, we first estimated a log form and then a linear form of WTP. The log-likelihood function attributable to the latter was higher $(-660.11)$ than that corresponding to the former $(-712.80)$, and thus, we concluded that the linear form of the interval was better than the log form.

For the variables such as sector, gender, education level, and international trade, we defined dummy variables. The dummy variables for the last two took a value of one if the owner's level of education was above university, and if the company traded internationally. For the other categorical variables, we defined a number of dummy variable equal to the number of categories minus one.

Of these characteristics, three appear statistically significant. They are the number of employees, the cost of transportation to the bank (named travel cost), and engagement in international trade. That is, the WTP for business online banking is a function of number of employees, travel cost, ${ }^{3}$ and international trade. This gives the estimated equation:

\author{
$W T P_{i}=$ constant $\mathrm{p} \beta_{\text {number }}$ of employees \\ $\mathrm{x}$ number of employees $\mathrm{p} \beta$ cost \\ $\mathrm{x} \operatorname{cost} \mathrm{p} \beta_{\text {international trade }}$
}




\section{xinternational trade}

Table 9 presents the STATA estimated coefficients. All coefficients are statistically significant at a $99 \%$ or $95 \%$ confidence level, and all signs are as expected. The coefficient for number of employees is positive, indicating that as the number of employees increases, the WTP of SMEs for online banking services will increase. Similarly, the cost coefficient is positive, indicating that as the travel cost rises, the WTP for online banking will increase. A positive value for SMEs' engagement in international trade indicates that SMEs engaged in international transactions will have a higher WTP.

To determine the goodness of fit of the model, we used the log-likelihood ratio (LL ratio) test, which is calculated as follows:

$\mathrm{LL}$ ratio $=-2 ð \mathrm{LL}$ of the base $\operatorname{model}^{4}-\mathrm{LL}$ of the estimated model $) \sim C h i-$ Square

First, we estimated the constant-only model with the log likelihood of -684.33 , and then, using equation (8), we calculated the value of the LL ratio. Comparing the calculated value (48.43) with the chi- square critical value with three degrees of freedom ${ }^{5}(7.815)$, we concluded that the model is better than the constant-only model.

Finally, the fitted value of WTP can be calculated using the estimated coefficients, which shouldbeconsidered as a reliable central tendency of unobserved WTP. Using STATA, we computed the fitted values and the resulting average WTP as \$518.5 per month. To determine whether engaging in international trade influences a company’s WTP for online banking, we used the resulting parameters and estimated the WTP of companies with and without international trade. 


\begin{tabular}{lc} 
Table 9. Interval regression results (number of observations $=386)$ \\
\hline & Coefficient \\
Variable & $(\mathrm{SE})$ \\
\hline Constant & $440.6641^{* * *}$ \\
& $(11.7284)$ \\
International trade & $44.9103^{* * *}$ \\
& $(11.1925)$ \\
Number of employees & $2.6039^{* * *}$ \\
& $(0.5767)$ \\
Travel cost & $0.1894^{* *}$ \\
& $(0.084)$ \\
Number of observations & 386 \\
Log-likelihood function & -660.1144 \\
Log-likelihood ratio & 48.43 \\
\hline
\end{tabular}

***99\% level of confidence

$* * 95 \%$ level of confidence

The results are shown in Table 10. The average WTP of companies with international trade $(\$ 528.00)$ is about $12 \%$ higher than for firms that are not engaged in international trade $(\$ 472.50)$.

In the next step, we estimated the WTP for online banking of firms in the three aforementioned categories according to their number of employees and travel cost.

We considered three numbers of employees $(5,12$, and 18) and substituted these in equation (7), along with the estimated parameters in Table 9 and the average values of the other variables, and calculated the WTP of the firms in the three different categories (all firms, and firms with and without international trade).

The computed values of WTP in Table 11 show that the firms' valuation of online banking increases by $16-18 \%$ as the number of employees in the firm increases from 5 to 18 employees. It is also clear that in each of the three size categories, the WTP value for firms with international trade is higher than the average for all firms and for firms without international trade. This indicates that online banking is more valuable for SMEs engaged 
in international trade, irrespective of their size.

For the travel cost variable, since the middle $50 \%$ of observations lie between $\$ 21.80$ and $\$ 114.50$, we considered the WTP of firms in the three categories with three types of travel costs. We defined firms with travel cost of $\$ 21.80, \$ 43.60$, and $\$ 114.50$ as having low, medium, and high costs, respectively. We used the estimated parameters in Table 9, the average values of the other variables, and these three different amounts of travel cost again, substituted them into equation (7), and computed the firms' WTP. Table 12 shows the estimated WTP of these three categories of firms.

Table 10. Calculated WTP for online banking of firms with and without international trade.

\begin{tabular}{lc}
\hline Firms & Willingness to pay (\$) \\
\hline All firms & 518.5 \\
Firms with no international trade & 472.5 \\
Firms with international trade & 528.0 \\
\hline
\end{tabular}

Table 11. Comparison of the WTP of the sample firms according to the number of employees.

\begin{tabular}{lccc}
\hline Firm & WTP $(\$)$ of firms with 5 employees & WTP $(\$)$ of firms with 12 employees & WTP $(\$)$ of firms with 18 employees \\
\hline All firms & 522.50 & 568.73 & 608.35 \\
Firms with no international trade & 480.50 & 526.73 & 566.35 \\
Firms with international trade & 531.09 & 577.32 & 616.94 \\
\hline
\end{tabular}

Table 12. The estimated WTP for online banking of firms with three different levels of travel cost.

Firms WTP (\$) of firms with a cost of $\$ 21.60$ WTP (\$) of firms with a cost of $\$ 43.60$ WTP (\$) of firms with a cost of $\$ 114.50$

\begin{tabular}{llrl} 
All firms & 555.77 & 559.90 & 573.32 \\
Firms with no international trade & 510.83 & 514.96 & 526.39 \\
Firms with international trade & 562.35 & 566.47 & 579.90 \\
\hline
\end{tabular}


Like the previous table, Table 12 shows that the WTP of firms with international trade is higher than the WTP for all firms and for those with no international trade. It also shows that as the travel cost increases, the WTP also increases. However, the increase is modest, with only a $3 \%$ difference between the lower and upper bound of the range of travel costs associated with this sample of firms. Comparing the results in Tables 11 and 12, it is clear that the impact of size (in terms of employee numbers) is greater than the effect of travel costs on the firms' WTP for online banking services.

\section{Conclusion}

The provision of improved banking services for SMEs will help to meet the policy goal of improving international trade in the UAE. This is a policy conclusion that is likely to hold for any transitional economy that has obsolete banking regulations with respect to the operation of online banking systems. A reliable online banking facility could play a key role in enhancing international trade, providing SMEs with specialized, convenient, and low-cost services. The results of this study demonstrate that the average SMEs'WTP for online banking services is $\$ 518.5$ per month, reflecting the value of the increased convenience, including the savings in transportation and employee (salary) costs, com- pared with traditional branch banking.

If most of the UAE free zone firms (9,976 companies) were to utilize online banking services, the cumulative time and cost savings would be very substantial. A rough estimate would be $\$ 62.1$ million per year $(\$ 518.5 \times 12 \times 9$; 976P: Furthermore, online banking is associated with a reduction in demand for in-branch transactions, resulting in a decrease in bank operating costs (Aladwani 2001) and a lowering of the incidence of internal fraud.

The results also show how this value changes with the nature of the firm (i.e. is it engaged in 
international trade or not, and the size of the firm as measured by the number of employees) and the distance of the firm from conventional banking services as measured by travel cost. These variables have an important impact, as expressed by the owners or the managers, on the value that is derived from the service by the firms. These issues have not been studied previously by the research in this field. These characteristics that affect the value of service, are related directly with the features of the businesses and are not specific to any one country. The extensive mix of nationalities of the people interviewed also helps to mitigate any potential cultural bias that might exist in the acceptance and valuation of this service by the managers or owners of such SMEs.

A policy implication of this study is that the government should provide appropriate legislative and regulatory frameworks to allow banks to pro- vide round-the-clock, secure online banking services. Such an advancement in service provision would not only yield a very substantial benefit to SMEs, but would also be likely to reduce the operating costs of the banks.

In our survey we considered 'internet banking' and did not differentiate between mobile banking and computer based internet banking. The measurement of the difference in value between a service that is only computer based and one that is mobile telephone based is an interesting topic for future research.

\section{Disclosure statement}

No potential conflict of interest was reported by the authors. 
References

Ajayi, A. O. 2006. “An Assessment of Farmers' Willingness to Pay for Extension Services Using the Contingent Valuation Method: The Case of Oyo State, Nigeria." Journal of Agricultural Education and Extension 12 (2): 97-108. doi:10.1080/13892240600861567.

Aladwani, A. M. 2001. "Online Banking: A Field Study of Drivers, Development Challenges, and Expectations." International Journal of Information Management 21 (3): 213-225. doi:10.1016/s0268-4012(01)00011-1.

Al-Somali, S. A., R. Gholami, and B. Clegg. 2009. "An Investigation into the Acceptance of Online Banking in Saudi Arabia.” Technovation 29 (2): 130-141. doi:10.1016/ j.technovation.2008.07.004.

Amigues, J. P., C. Boulatoff, B. Desaigues, C. Gauthier, and

J. E. Keith. 2002. "The Benefits and Costs of Riparian Analysis Habitat Preservation - A Willingness to Accept/ Willingness to Pay Contingent Valuation Approach.” Ecological Economics 43: 17-31. doi:10.1016/S0921- 8009(02)00172-6.

Beck, T., A. Demirguc-Kunt, and R. Levine. 2005. "SMEs, Growth, and Poverty: CrossCountry Evidence.” Journal of Economic Growth 10 (3): 199-229. doi:10.1007/s10887005-3533-5.

Bernard, A. B., J. B. Jensen, S. J. Redding, and P. K. Schott. 2007. "Firms in International Trade." The Journal of Economic Perspectives 21 (3): 105-130. doi:10.1257/ jep.21.3.105.

Blaine, T. W., F. R. Lichtkoppler, and R. Stanbro. 2003. “An Assessment of Residents' Willingness to Pay for Green Space and Farmland Preservation Conservation Easements Using the Contingent Valuation Method (CVM).” Journal of Extension 41: 4.

Bosetti, V., and D. Pearce. 2003. “A Study of Environmental Conflict: The Economic Value of Grey Seals in Southwest England.” Biodiversity \& Conservation 12 (12): 2361-2392. 
Calisir, F., and C. A. Gumussoy. 2008. "Internet Banking versus Other Banking Channels: Young Consumers' View.” International Journal of Information Management 28 (3): 215-221. doi:10.1016/j.ijinfomgt.2008.02.009.

Cameron, T. A. 1991. "Interval Estimates of Non-Market Resource Values from Referendum Contingent Valuation Surveys." Land Economics 67 (4): 413-421. doi:10.2307/ 3146548.

Cameron, T. A., and D. D. Huppert. 1989. "OLS versus ML Estimation of Non-Market Resource Values with Payment Card Interval Data." Journal of Environmental Economics and Management 17 (3): 230-246. doi:10.1016/0095- 0696(89)90018-1.

Cawley, J. 2008. "Contingent Valuation Analysis of Willingness to Pay to Reduce Childhood Obesity." Economics \& Human Biology 6: 281-292. doi:10.1016/j. ehb.2008.05.003.

Cummins, J. D., C. M. Lewis, and R. Wei. 2006. “The Market Value Impact of Operational Loss Events for US Banks and Insurers.” Journal of Banking \& Finance 30: 2605-2634. doi:10.1016/j.jbankfin.2005.09.015.

Diamond, P. 1996. "Testing the Internal Consistency of Contingent Valuation Surveys." Journal of Environmental Economics and Management 30 (3): 337-347. doi:10.1006/ jeem.1996.0023.

Diamond, P. A., and J. A. Hausman. 1994. "Contingent Valuation: Is Some Number Better than No Number?" The Journal of Economic Perspectives 8 (4): 45-64. doi:10.1257/jep.8.4.45.

The Dominion. 2001. "I-Banking Struggles for Profits". Retrieved from http://www.stuff.co.nz/inl/index/ 0,1008,779016a28,FF.html

Eriksson, K., and D. Nilsson. 2007. "Determinants of the Continued Use of Self-Service 
Technology: The Case of Internet Banking." Technovation 27 (4): 159-167. doi:10.1016/j.technovation.2006.11.001.

Global Resources. 2012. Golden Rainbow: UAE Free Zones Directory. Dubai: Global Resources LLC.

Hanemann, W. M. 1984. "Welfare Evaluations in Contingent Valuation Experiments with Discrete Responses." American Journal of Agricultural Economics 696: 332-342. doi:10.2307/1240800.

Hausman, J. 2012. “Contingent Valuation: From Dubious to Hopeless.” The Journal of Economic Perspectives 26 (4): 43-56. doi:10.1257/jep.26.4.43.

Hausman, J. A., Ed. 1993. Contingent Valuation: A Critical Assessment. North Holand, Emerald Group Publishing Limited. doi:10.1108/50573-8555(1993)220.

Jayawardhena, C., and P. Foley. 2000. "Changes in the Banking Sector: The Case of Internet Banking in the UK." Internet Research: Electronic Networking Applications and Policy 10 (1): 19-30. doi:10.1108/

10662240010312048.

Jordan, J., and J. Katz. 1999. "Banking in the Age of Information Technology." http://www.bostonfed.org/publi cations/regional-review/1999/quarter-4.

Kim, Y. 2005. "Estimation of Consumer Preferences on New Telecommunications Services- IMT-2000 Service in Korea." Information Economics and Policy 17: 73-84. doi:10.1016/j.infoecopol.2004.03.002.

Kuisma, T., T. Laukkanen, and M. Hiltunen. 2007. "Mapping the Reasons for Resistance to Internet Banking: A Means-End Approach." International Journal of Information Management 27 (2): 75-85. doi:10.1016/j. ijinfomgt.2006.08.006.

Lee, H., and H. Tanaka. 1999. "Upper and Lower Approximation Models in Interval 
Regression Using Regression Quantile Techniques.” European Journal of

Operational Research 116 (3): 653-666. doi:10.1016/S0377- 2217(98)00191-X.

Lindhjem, H., and S. Navrud. 2011. "Are Internet Surveys an Alternative to Face-To-Face Interviews in Contingent Valuation?" Ecological Economics 70: 1628-1637. doi:10.1016/j.ecolecon.2011.04.002.

Loureiro, M. L., S. And, and S. Hine. 2002. "Discovering Niche Markets: A Comparison of Consumer Willingness to Pay for Local (Colorado Grown), Organic, and GMO-free Products." Journal of Agricultural and Applied Economics 34 (03): 477-487. doi:10.1017/S1074070800009251.

Mahieua, P. A., P. Rierab, and M. Giergicznyc. 2012. "The Influence of Cheap Talk on Willingness-To-Pay Ranges: Some Empirical Evidence from a Contingent Valuation Study." Journal of Environmental Planning and Management 6 (55): 753-763. doi:10.1080/09640568.2011.626524.

Martins, C., T. Oliveira, and A. Popovič. 2014. "Understanding the Internet Banking Adoption: A Unified Theory of Acceptance and Use of Technology and Perceived Risk Application." International Journal of Information Management 34 (1): 1-13. doi:10.1016/j. ijinfomgt.2013.06.002.

Nomura, N., and M. Akai. 2004. "Willingness to Pay for Green Electricity in Japan as Estimated through Contingent Valuation Method." Applied Energy 78: 453-463. doi:10.1016/j.apenergy.2003.10.001.

Ozbafli, A., and G. P. Jenkins. 2015. "The Willingness to Pay by Households for Improved Reliability Electricity Service in North Cyprus.”Energy Policy 87: 359-369. doi:10.1016/ j.enpol.2015.09.014. 
Polatoglu, V. N., and S. Ekin. 2001. “An Empirical Investigation of the Turkish Consumers' Acceptance of Internet Banking Services.” International Journal of Bank Marketing 19 (4): 156-165. doi:10.1108/02652320110392527.

Sathye, M. 1999. “Adoption of Internet Banking by Australian Consumers: An Empirical Investigation."

International Journal of Bank Marketing 17 (7): 324-334. doi:10.1108/02652329910305689.

Saz-Salazar, S. D., and L. Garcia-Menendez. 2001. "Willingness to Pay for Environmental Improvement in a Large City.” Environmental and Resource Economics 20: 103-112.

Seip, K., and J. Strand. 1992. "Willingness to Pay for Environmental Goods in Norway: A Contingent Valuation Study with Real Payment." Environmental and Resource Economics 2: 91-106. doi:10.1007/BF00324691.

Shah, M. H., and F. A. Siddiqui. 2006. “Organisational Critical Success Factors in Adoption of E-Banking at the Woolwich Bank." International Journal of Information Management 26 (6): 442-456. doi:10.1016/j. ijinfomgt.2006.08.003.

Venkatachalam, L. 2004. "The Contingent Valuation Method: A Review." Environmental Impact Assessment Review 24(1): 89-124. doi:10.1016/S0195-9255(03)00138-0.

Voltaire, L. 2015. "Respondent Direct Experience and Contingent Willingness to Pay for New Commodities: A Switching Endogenous Interval Regression Analysis." Applied Economics 47 (22): 2235-2249. doi:10.1080/

00036846.2014 .1002890$.

Yiu, C. S., K. Grant, and D. Edgar. 2007. "Factors Affecting the Adoption of Internet Banking in Hong Kong- Implications for the Banking Sector.” International Journal of Information Management 27 (5): 336-351. doi:10.1016/j.ijinfomgt.2007.03.002.

Yousafzai, S. Y., J. G. Pallister, and G. R. Foxall. 2003. "A Proposed Model of E-Trust 
for Electronic Banking.” Technovation 23 (11): 847-860. doi:10.1016/S01664972(03)00130-5.

Zhongmin, X., C. Guodong, Z. Zhiqiang, and S. Zhiyong. 2003. “Applying Contingent Valuation in China to Measure the Total Economic Value of Restoring Ecosystem Services in Ejina Region." Ecological Economics 44: 345-358. doi:10.1016/S09218009(02)00280-X. 